This is a peer-reviewed, accepted author manuscript of the following book review article: Foran, M. (2022). [Book review]: John Laws, The Constitutional Balance. Edinburgh Law Review, 26(1), 144-147. https://doi.org/10.3366/elr.2022.0754

\title{
John Laws, THE CONSTITUTIONAL BALANCE
}

Oxford: Hart Publishing (www.bloomsburyprofessional.com/hart/), 2021. ix +144 pp. ISBN: $9781509935451 . £ 30$.

Sir John Laws was and will remain a towering figure within UK constitutional law scholarship. Much, although not nearly enough, has already been said to commemorate his intellect and wit, both of which leap off the pages of this, his final published work. Reviewing a book in these circumstances is peculiar. Sir John Laws was an intellectual hero of mine. Given that, and the contemporaneousness of his death, it seems fitting to stress some of the finer qualities of his character, as a jurist and as a man. Yet, space constraints make that difficult and my suspicion is that Sir John himself would much rather get to the meat and potatoes of things anyway. Whatever might have been said in an opening paragraph of this kind would not have done justice to the man nor to the legacy that will endure long after most of his contemporaries have faded into obscurity.

The Constitutional Balance is an excellent book. It represents the culmination of a lifetime of deep thinking about the nature of UK constitutional law. Anyone remotely interested in constitutional theory should read this book. Coming in at just under 150 pages, Laws has managed to distil the central features of his judicial philosophy into a concise and easily accessible treatise on the common law constitution. The central aim is to defend a model of constitutionalism grounded in fundamental principles and values. Common law ideals of reason, fairness, and the presumption of liberty interact with equally foundational principles of democracy and the separation of powers, sometimes conflicting. To Laws, this conflict must be resolved by balancing what he describes as the two moralities of law and government.

While the precise character of these two moralities warrants greater analysis with more nuance than Laws could provide in this book, the key insight remains valuable. It should come as no surprise that government and the judiciary do different things in different ways when interacting with law. Laws provides the useful explanation that this is not simply a matter of separated functions but of distinct role moralities, each institution of state having an affinity for particular ethical traditions. On his view, "Politicians, governments, are by necessity utilitarians ... their primary focus is on outcomes" (41). In contrast, the judiciary adopt a Kantian morality because "Rights and duties are necessarily and honourably the moral language of justice and therefore law" (41). The terminology here is somewhat reductionist; while common law is of its nature deontic, it is inaccurate to describe the business of government as automatically utilitarian rather than teleological. Utilitarianism is concerned with consequences in the way that all governments are, but it presupposes an aggregative, majoritarianism filtered through a lens of utility that not all governments adopt in their pursuit of the public interest. A teleological normativity which focuses more on the pursuit of particular ends, chosen by Parliament or government, would perhaps have been a better label to describe what Laws was getting at.

While separate functions are an important aspect of the Separation of Powers, it is the affinity that these functions have with distinct approaches to resolving moral and political issues that grounds the different moralities (42). Indeed, it is this insight that underpins Laws' rejection of ideology and his embrace of the methods of the common law: precedent, experiment, history, and distillation. It is through our practice and the development of principles that stand the test of time through continued application to concrete cases that we provide justice to individual claimants. Accordingly, the different moralities of government and the common law can never have a monopoly on the resolution of political questions under the rule of law: "The constitutional balance is the means by which our law gives practical application to constitutional principles that ... are ... the foundation of the Rule of Law" (1).

Any perspective which imposes external standards to presuppose the outcome of a deliberative process, even those grounded in fundamental rights claims, must be rejected. In fact, Laws is explicit that "it is the ideology of fundamental rights and freedoms that there is no ideology" (2). By this I think we can derive a rejection of the concept of rights as inputs into an interpretative process, fully formed and completely determinate externally to the practice or community to which they apply. Instead, the balance views rights as the output of an interpretative process, properly accounting for all the constitutional considerations in view, including a need to respect the distinct morality of government in determining relevant issues relating to the public interest. It is for this reason that Laws suggests that "deference marks the courts' recognition that as regards the merits of the use of discretionary power in any given instance, the public body to which the power has been delegated by Parliament is the primary 
decision-maker; that is required if effect is to be given to Parliament's authority as the source of the power in question" (90).

This being the case, however, we are then presented with a question that occupies much of this book: how do we balance democratic authority against fundamental principle? The answer can only come once we have a clearer picture of what Parliament's authority consists in; or more precisely, how its authority manifests within statute. To Laws, "The meeting of Parliament and the common law, in the crucible of statutory interpretation, is close to the core of [the constitutional balance]" (57). This is because "the foundational principles that give life to the Rule of Law are the very guardians of democracy's integrity" (32). Yet this itself is only intelligible because democracy presupposes that the legislature is "required to treat our fundamental norms and standards, not as an alien force, but as part of its own proper function" (114). In perhaps the finest chapter in the book, Laws takes aim at the wildly popular but woefully misguided notion of Parliamentary intent. In thirteen short pages, Laws distils the core of the common law constitutional critique of the fallacy that a collective body such as Parliament can have any intention beyond passing the words on a given page into law. Epistemically that is all that it could have intended; empirically that is all that could possibly be discovered; and normatively that is all that is desired. As Laws notes, "A group does not have a mind, and therefore cannot possess a state of mind" (97). What matters for statutory construction is the purpose of the statute and this can only be determined in light of our fundamental constitutional principles (102).

Having said that, this insight creates some serious problems for Laws' own theory. The first, and I think most problematic, given the title of this book, is that this approach appears to completely dissolve any balancing that might be done between fundamental common law principle and the value of democracy. This would have been apparent even from a deeper analysis of the nature of the two moralities of government and the judiciary: balance implies opposing forces that come to some compromise; but deontic (or Kantian) constraints set limits on acts, even those used as means to pursue legitimate ends. These principled limits, and the duties and rights derived from them, cannot be compromised without being breached. There is no real balancing to be done, on this view, because teleology and deontology (at least in this context) operate on different levels: one determines the ends that ought to be pursued and the other rules out certain means used in the pursuit of those ends. I have argued elsewhere that the rule of law will also necessarily place limits on the ends that can legitimately be pursued (Foran, "The Rule of Good Law: Form, Substance, and Fundamental Rights" (2019) 78(3) CLJ 570).

While there is no balancing to be done at this structural or conceptual level, it would be a mistake to abandon the idea of balance altogether. When determining what statute means and what is required by common law principle, Laws is quite right to insist that all relevant constitutional considerations must be taken into account. This means that the precise requirements of these deontic limits must themselves include constitutional values of democracy and political equality. It is this which explains the distinction between appeal and review, essential for the legitimacy of judicial review. Courts must enforce fundamental principle to ensure that public power is exercised justly, but they must equally refrain from adopting an ideological approach to rights questions which draws exclusively on external moral standards, or which fails to account for the particularities of a given case. The rule of law demands recognition of the proper role of government and Parliament in determining what is in the public interest. So long as that determination does not breach fundamental principles of justice, understood in light of all relevant considerations, then it will be lawful. If there is a balance at this level, it is one that manifests a kind of reflective equilibrium that a common law court must engage in; interpreting the purpose of a statute by reference both to its text and to fundamental principles which demand recognition of the distinct moralities in play. Once the requirements of fundamental principle are determined, however, no further deference or balancing can be engaged in. The limits are known, and government must respect them.

Perhaps a better way to describe this process of interpretation would be constitutional harmony, given that these two moralities work together to foster the common good. Indeed, the respect shown to democratic authority must genuinely be repaid, with Parliament and government not simply picking random ends, but by internalising the moral underpinnings of common law principle: the conception of man as a dignified person inherent in legality. When this is done, the democratic organs of state direct public power towards the flourishing of all members of our society, not as a mater of utilitarian calculus, but of a genuine common good, appropriately respectful of constitutional principle. 
The second problem that Laws' theory of statutory construction raises is one which directly undermines his own concept of Constitutional Statutes. He summarises the doctrine of implied repeal as follows: "if Parliament has enacted successive statutes that, on the true construction of each of them, make irreducibly inconsistent provisions, the earlier statute is impliedly repealed by the later." (112). Leaving aside the over-inclusiveness of this definition (only inconsistent provisions would be repealed, not the whole statute), we can already see the significance of the requirement that this must occur on the true construction of each. However we determine which statutes qualify as constitutional, the theoretical implication of their existence is that the doctrine of implied repeal does not apply to them. What this means is that where two statutes, on the true construction of each, conflict with one another, and one is a constitutional statute, a new construction is demanded which will interpret the nonconstitutional statute to be compatible with the constitutional one. Yet, if construction requires determination of the purpose of a statute in light of fundamental principle, and if constitutional statutes are so because they manifest fundamental principles, then surely the true construction would already be the non-conflicting one? A common law constitutionalist cannot accept that there are multiple true interpretations of a statute, let alone that one of these would entail the breach of fundamental principle. If we accept Laws' account of statutory construction, then the significance of Constitutional Statutes falls away because the doctrine of implied repeal is not applicable, precisely because the true construction of any statute is always a constitutionally acceptable one.

These issues aside, this book warrants careful reading by anyone working in constitutional theory and will be an invaluable resource for students. I expect that many chapters, if not the entire book, will find a home on reading lists across the United Kingdom and beyond. Laws has managed to provide a thoroughly accessible book that is nevertheless nuanced and insightful. A fitting final publication for a man whose writing has always struck that balance so well.

Michael Foran University of Strathclyde 